\title{
REINFORCING AUTHORITARIAN RULE Electoral Politics in Angola
}

\author{
Lesley Blaauw
}

Dr Lesley Blaauw is Senior Lecturer in the Department of Political and Administrative Studies, Faculty of Economic and Management Science University of Namibia e-mail: lblaauw@unam.na

\begin{abstract}
In the aftermath of the conclusion of the peace process in Angola in 1992 the Angolan government managed to establish formal democratic institutions. Foremost on the agenda was the decision to allow for multiparty elections. Yet the launch of electoral politics as part of the democratic landscape in Angola has not led to the development of a culture of tolerance and openness typical of democratic societies. On the contrary, the outbreak of a civil war following the disputed elections in 1992 gave the Angolan government the opportunity to revert to its authoritarian ways. The consequence of this reversal was that the elections of 2008 have not led to the entrenchment or the development of electoral democracy but rather to the reinforcement of electoral authoritarianism. This article posits that while the foundation for the evolution of electoral democracy has been laid, the Angolan government can, at best, be described as an electoral authoritarian state that reinforces its hegemony over Angolan society through electoral processes which do not conform to democratic practices.
\end{abstract}

\section{INTRODUCTION}

The end of the conflict in Angola in 1991 which resulted in the signing of the Bicesse Accords between the Popular Movement for the Liberation of Angola (MPLA) and the National Union for the Total Independence of Angola (Unita) has seen the advent of a new phase in the history of that country. The daunting challenge which awaited the country in the aftermath of the protracted war that had raged since independence was profoundly embedded in the genesis of the Angolan state. 
Like other fractured states in the Southern African region, the Angolan state today bears the imprint of colonialism and authoritarianism. Moreover, the fractious nature of Angola's accession to independence, characterised by the polarisation between and among the liberation movements, arguably left deep footprints in the establishment of durable democratic institutions.

It is fair to argue that the social contract between the ruling elite and the general populace was never based on a solid edifice, primarily because of the historically ruptured nature of politics in Angola. Thus politics in the country is marked by a rupture between the political elite and the general populace and the end of the war has not necessarily resulted in the emergence of a democratic culture or a democratic tradition.

From the above reading, Angola, like most states in Southern Africa can, at best, be described as a dominant-party state. Dominant parties, Bogaards (2004) contends, are defined by four criteria: the urge for dominance, the inclusion/ exclusion of opposition features, the presence or absence of divided government and the ability of such a government to reproduce itself by winning consecutive elections.

Angola did not evolve from an authoritarian regime to a democratic one, as was generally expected. The problems of transition to a democracy are lucidly captured by Khabela Matlosa (2008, p 5), who asserts that

embarking on a road to democracy is one thing and sustaining a democratic moment is quite another. Put somewhat differently, it is easy to put together a democracy roadmap and begin a journey on a democratic path, but rather difficult to ensure that the democratic moment is both sustainable and irreversible.

In the case of Angola it could be argued that the transition from authoritarianism to democracy has, in fact, stalled since the first democratic elections, in $1992 .{ }^{1}$

Michael Bratton and Nicolas van de Walle (1997, p 120) posit that

a blocked transition is one in which political reforms were launched but never fully realized ... rulers made insincere and tactical concessions aimed at buying time to shore up collapsing authority, with an apparent intention of implementing elections or surrendering power.

1 The Angolan regime could best be described as an electoral authoritarian one, marked by a transition that took place, but not successfully, in part because of the lack of political stability (Matlosa 2008, p5). 
Despite the fact that the transition to democracy in Angola has stalled, the MPLA government has been able to put up a façade of democracy by holding elections, albeit irregularly.

The institution of elections has allowed the government, like those in most authoritarian regimes, to develop strategies to contain and manage demands to democratise. For Carrie Manning (2005, p 708), this provides 'limited opportunities for the emergence of alternative power centres outside of the state'. Indeed, what will be illustrated is that the Angolan government uses the electoral arena to control forms of political contestation.

By holding elections that allow for a modicum of pluralism the government has ensured a degree of secured controlled representation, which does not fundamentally undermine its power (Magaloni 2006, p 258). In addition, the holding of elections has also had an impact on the relationship between the ruling party and the citizens. This is because elections, by their very nature, have the ability to generate public legitimacy (Schedler 2002, p 36).

This article first explores the differences between electoral democracy and electoral authoritarianism. Secondly it reflects on the management of elections in Angola. Thereafter, the outcomes of the elections that have been held are examined and the article concludes with an evaluation of the prospects for democracy in Angola.

\section{CONCEPTUALISING ELECTORAL AUTHORITARIANISM AND ELECTORAL DEMOCRACY}

The holding of elections by governments in Africa has not only been credited for the emergence of a democratic continent but is also considered to be of great significance (Lindberg 2006, p 139). The importance attached to elections as a progenitor of democratic legitimacy and, by extension, broader political participation and democratic accountability, has been questioned (Carothers 2002, pp 5-6). In particular, the postulate that multiparty election can provide the edifice upon which further democratic reforms can be built, has also received considerable scrutiny (Ake 1996; Bratton 1998; Carothers 1997).

Despite these divergent ideas about the feasibility of elections as a generator of democratic reform, the holding of elections is still seen as a central requirement for democratic qualification (Diamond 2005, p 14). Saheed Adejumobi (2000, p 60 ) contends that the role and essence of elections in a democracy are highly circumscribed in terms of expressing the popular will, engendering political changes and the legitimation of political regimes.'

Elections are, therefore, central to the renewal of the democratic system of any country, thus suggesting that regular elections bestow electoral legitimacy on any government. 
A minimalist conception of democracy limits it to the holding of free and fair elections. However, a broad-based definition requires more. In this regard, Larry Diamond (2002, p 21) asserts that

democracy requires not only free, fair and competitive elections, but also the freedoms to make them truly meaningful (such as freedom of organization and freedom of expression), alternative sources of information, and institutions to ensure that government policies depend on the votes and preferences of citizens.

This suggests that elections are a necessary but not sufficient condition for the proper functioning of democracy. So what, then, is the distinction between electoral authoritarianism and electoral democracy? Wolfgang Merkel (2004, p 34) asserts that: 'Electoral democracy merely entails that the election of the ruling elite be based on the formal, universal right to vote, such that elections are general, free and regular.'

The term electoral democracy is, therefore, theoretically incomplete and not very useful analytically. Electoral democracy

reduces democracy to the correct procedure of democratic elections, but it does not include sufficient institutional guarantees that assure that those elections are 'meaningful', or that the democratically elected elites will rule according to the fundamental constitutional principles of democracy.

Merkel 2004, p 37

Electoral democracy also requires that the administration of elections is sufficiently autonomous and professional and that contending parties and candidates are sufficiently free to campaign that the political opposition has a fair chance of defeating the government in further elections (Diamond 2002, p 22; Levitsky \& Way 2002, 2010, p 7). Arch Puddington (2007, p 3) contends that adherence to the following criteria ensures that a country qualifies as an electoral democracy:

a competitive political system; universal adult suffrage for all citizens; regularly contested elections under a secure and secret ballot and the absence of massive, outcome-changing fraud; significant public access of major political parties to the electorate through the media and open campaigning. 
Electoral democracies, by their very nature, concern themselves with civil liberties, while electoral authoritarian regimes view the functions of elections differently.

Andreas Schedler (2002, p 37) asserts that electoral authoritarian regimes hold elections: '.. to reap the fruits of electoral legitimacy without running the risk of democratic uncertainty'. For Hadenius \& Teorell (2007, p 154) 'multiparty regimes have become the most common form of authoritarian governments', while Andreas Schedler (2006, p 3) further postulates that

[e]lectoral authoritarian regimes play the game of multiparty elections by holding regular elections for the chief executive and a national legislative assembly. Yet they violate the liberal-democratic principles of freedom and fairness so profoundly and systematically as to render elections instruments of authoritarian rule rather than 'instruments of democracy'.

In short, electoral authoritarian regimes normally adopt the forms of democracy even as they resist substantive democratisation (Brownlee 2009). Fundamentally in such regimes the checks and balances needed for the proper functioning of democracy are undermined. From the above reading, electoral authoritarian regimes 'lack an arena of contestation sufficiently open, free, and fair so that the ruling party can readily be turned out of power if it is no longer preferred by a plurality of the electorate' (Diamond 2002, p 24).

In the case of Angola, '[e]lections have been an instrument of authoritarian control as well as a means of democratic governance' (Schedler 2002, p 37). This is because elections in Angola are contested in a lopsided political arena. In this context elections help rulers manage their opponents by co-opting them (Joseph 1997, p 377; Magaloni, 2006, p 44).

In addition to the above, under electoral authoritarian regimes electoral contests are subject to state manipulation so severe, widespread and systematic that they do not qualify as democratic (Schedler 2006, p 3). Moreover, the conduct of free and fair elections in such regimes is non-existent, despite the fact that they open up political society as well as limited forms of pluralism (Schedler 2006, p 3).

But even the opening up of political space for contending views fulfils a sinister purpose. Magaloni (2006, p 44) contends that the utility of elections under electoral authoritarian regimes could potentially serve as a divisive mechanism for opposition parties by inducing them to compete in such elections. The façade of democracy under electoral authoritarian regimes finds expression in the establishment of formal democratic institutions such as bodies to manage elections. 


\section{SETTING THE PATTERN FOR AUTHORITARIANISM IN ANGOLA: THE 1992 NATIONAL ELECTIONS}

Changes in the international environment as well as a military stalemate (the battle at Cuito Cuanavale) facilitated the New York accords relating to the independence of Namibia that were linked to the withdrawal of Cuban troops from Angola. This created pressure on the MPLA to begin negotiating with Unita.

The loss of the Cuban troops was exacerbated by the fact that the Soviet Union ended its military aid to the MPLA and the international market price for oil decreased considerably. The amendments to the constitution of the MPLA government in 1990 signalled the end of the Marxist-Leninist party doctrine and the advent of electoral democracy in Angola. The elections were the result of negotiations between the two protagonists in the Angolan civil war, the MPLA and Unita.

The negotiations for peace started in Bicesse, in Portugal, and lasted from April 1990 to May 1991, with the involvement of Portugal and the two superpowers (Ottaway 1998, p 133). The Bicesse Accords, signed by both parties, provided for the holding of elections and the introduction of a multiparty system.

The first multiparty elections for both the president and the legislature were held in Angola on 29 and 30 September 1992, overseen by the United Nations Verification Mission (UNAVEM), which was also mandated to oversee the peace process. As shown in Table 1, the MPLA won the parliamentary elections with $54 \%$ of the vote against the $34 \%$ won by Unita. The National Liberation Front (FLNA) won $2.4 \%$, with the remaining $9.8 \%$ divided among smaller parties. In the presidential elections Jonas Savimbi of Unita took $40.1 \%$ while José Eduardo dos Santos of the MPLA won $49.6 \%$. The promise of a second round of presidential elections never materialised, which resulted in another civil war (Orre 2010, p 5) when Savimbi contended that the MPLA had committed electoral fraud.

The civil war enabled the MPLA to reinforce its control over both state and society (Messiant 2001, p 290). The fact that Unita did not accept the outcome of the 1992 elections also meant that it suffered from a 'democratic deficit', creating circumstances that reinforced the legitimacy of the MPLA government. Christine Messiant (2001, p 291) contends that

these circumstances permitted the MPLA party to reinforce its grip on every organ of state, a party takeover underpinned by an absolute majority in parliament and domination of the government. Another trump card was international position, since the international community was now seeing the MPLA as the legitimate government of Angola, a position which was to be further strengthened by the United Nations' vote in 1997 of new sanctions against UNITA. 
This external validation significantly increased the legitimacy of the MPLA both within and outside the country. Moreover, it set a pattern of politics marked by increasing tendencies of the Angolan state towards authoritarianism.

Table 1

The 1992 National Assembly Election Results

\begin{tabular}{|l|c|c|c|}
\hline Party & Votes & \% Votes & Seats \\
\hline MPLA & 2124126 & 53.74 & 129 \\
\hline Unita & 1347636 & 34.10 & 70 \\
\hline FLNA & 94742 & 2.40 & 5 \\
\hline Nine other parties & 333554 & 8.43 & 0 \\
\hline Six other parties & 51219 & 1.32 & $\mathbf{2 2 0}$ \\
\hline Total & 3951277 & $\mathbf{9 9 . 9 9}$ & 16 \\
\hline
\end{tabular}

Source: Lodge et al 2002, p 28

The civil war which ensued lasted for another ten years, only stopping after the death of Savimbi in 2002. The war had implications for the emergence of a democratic state in Angola. The politicisation of political institutions by the MPLA after the 1992 elections meant it could use the election outcome to generate public legitimacy (Schedler 2002, p 36).

Inge Amudsen (2011, p 2) argues that it took the Angolan government six years to establish its hegemony over most of society and feel relatively secure in determining a date for the 2008 elections. ${ }^{2}$ In the final analysis, the 1992 elections ensured a return to authoritarianism because of the regime's economic control, the politicisation of political institutions and the international legitimacy bestowed on the MPLA government by the international community.

2 The Bertelsmann Stiftung (2012) report notes that the hegemonic control the MPLA gained over society derived from an 'authoritarian conversion'. 'Its main thrust was a consolidation of the macroeconomic situation, accompanied by a construction boom (infrastructure, housing, office buildings, hotels, etc), an expansion and diversification of the service sector, increased state efficiency, a number of social measures, and an administrative "deconcentration"' $(2012, \mathrm{p} 7)$. In this trajectory the three pillars of regime stabilisation - economic control, state capacity and international validation - all conspire to keep democratisation at bay in Angola. 


\section{REINFORCING AUTHORITARIANISM: THE GENERAL ELECTIONS OF 2008}

The outbreak of war after the 1992 elections created a propitious environment for the MPLA to re-establish its hegemony over Angolan society. Both the internal environment and the external validation the government received contributed to the return to the politics of authoritarianism. As in other authoritarian states, the upgrading of authoritarianism - to invoke Steven Heydemann's term - took place in Angola in a number of phases. Heydemann $(2007, \mathrm{p} 1)$ posits that 'authoritarian upgrading involves reconfiguring authoritarian governance to accommodate and manage changing political, economic, and social conditions.'

In the build-up to the 2008 elections the mechanisms put in place by the MPLA government meant that its hegemonic project was complete. The democratic gains achieved through the 1992 elections were eroded by the government by a series of actions. As has become the norm in authoritarian regimes, the government prohibited Angolans living abroad from voting. It also used state resources for the benefit of the ruling party (Amudsen 2011, pp 2-3). The absence of an independent electoral body meant that the government, like most authoritarian governments, made rules to suit it.

The ruling party also used economic resources to tighten its authoritarian grip on power. The stranglehold that Dos Santos and his cronies have on the Angolan economy is succinctly explained in the claim by Vines, Shaxson, Rimli \& Heymans $(2005, \mathrm{p} 6)$, who have noted that

Angola's economy is strongly controlled by a presidency that wields power through personalized networks which, as in many African countries, can be more important than the ministers and other formal institutions.

The MPLA's complete control over state and society and the feebleness of the opposition means expanded opportunities for economic and social elites. This control is most pronounced in the oil sector. The Angolan president used and still uses loans backed by Sonangol, a parastatal that oversees petroleum and natural gas production in Angola, and the revenue they generate.

through an extensive network of offshore accounts from which commissions were then paid to regime notables and foreign middlemen. While extremely onerous for the lender (the Angolan state), oil-backed loans provide the state elite with an easy source of money outside any sort of control.

De Oliveira, 2007, pp 606-607 (see also Malaquias 2001, p 319) 
To further assert its authority the MPLA government made efforts to control civil society. Among these efforts was the establishment of the Eduardo Dos Santos Foundation (FESA) in 1996 (Messiant 2001, p 287). The formation of this foundation, Christine Messiant argues (2001, p 289), represents 'a more general shift in the relationship between the Angolan regime and both national institutions and society'.

This assertion is premised on the conviction that the establishment of the foundation was aimed at further entrenching civil society under the influence of the ruling party in general and the presidency in particular. Moreover, it bears testimony to the constitution of political power and the way in which that power is exercised. For Messiant (2001, p 289), the formation of the foundation bears testimony to the fact that the

tenure of actual power in Angola is thus increasingly centralized and, although power is exercised largely by ignoring or subverting the formal institutions defined by law, those who wield it are able to reinforce their control of such institutions at the same time as they maintain their grip over both legal and illegal sectors of the economy, thus acquiring a certain degree of penetration of society.

The 2010 Angolan Constitution and legal framework largely conform to international norms. However, there remains a huge gap between these constitutional provisions and the state's enforcement of fundamental freedoms. For instance, the country's legal framework establishes a number of restrictions on the rights to association and assembly. This is particularly relevant in the domains of human rights and advocacy.

The registration of NGOs in particular is characterised by a very cumbersome process. The organisation must first register at local level, after which it is required to seek permission from the Ministry of Justice or Provincial Commissioner. The Ministry of Justice can, in turn, request that the NGO seek approval from the national government body, the Technical Unit for the Coordination of Humanitarian Assistance (UTCAH), before issuing a certificate. UTCAH, in turn, may request authorisation from the Ministry of Justice or any other ministry before approving the application (http//www.usiad.gov/our-work/democracy-andgovernance). Needless to say, this process can take years to finalise.

These constraints have hampered the ability of political parties and civic organisations to exercise their rights to the full. Also, the way in which the Angolan government treats NGOs illustrates the stifling domestic environment. A presidential decree of December 2002 seems to be an instrument with which to discipline NGOs. Amongst other things, it provides that they must not engage in 
political activities and must work only as partners of government (Bertelsmann Stiftung 2012, p 20).

For all these reasons the 2008 elections, held on 5 and 6 September, took place on a very uneven playing field.

However, they were much more organised than the previous elections. For instance, a new legal framework saw the establishment of an Inter-ministerial Commission for the Preparations of Elections (CIPE), charged with the task of handling the technical implementation of the election process, and a National Electoral Commission (CNE) responsible for the conduct of elections and voter registration (Campos 2008, p 4). The power of incumbency and the authoritarian nature of the MPLA government allowed it to use the CNE to its advantage (Bertelsmann Stiftung 2012, p 12).

To prevent the mayhem which followed the 1992 elections the government also improved security, ensured the participation of women and came up with a voter registration roll deemed to be the best in Africa (BTI 2012, p 5). More significantly, greater political space was accorded to civil society in the build-up to the elections. Through the Electoral Platform of Civil Society for Elections (PNASCAE), civil society organisations were active throughout the registration process (BTI 2012, p 7).

The 2008 elections, like those in 1992, were won by the MPLA. The difference was the margin. The MPLA secured $81.6 \%$ of the vote as opposed to Unita's $10.4 \%$. The rest of the votes were divided among the smaller parties (Amudsen 2011, p 5; Orre, 2010, p 9). The outcome of the 2008 elections - which were, to all intents and purposes, non-competitive (Levitsky \& Way 2002, pp 54-55) - reinforces the claim that Angola is an electoral authoritarian regime - they failed to create the uncertainty that typifies democratic countries, instead reinforcing the power of the government (Magaloni 2006, p 258).

The margin with which the MPLA won the 2008 elections reflects the pattern of politics in Africa, which favours the incumbent, thus creating an 'uneven' playing field. Moreover, it accorded the MPLA government the legitimacy it did not receive in the 1992 elections. The advantage of incumbency and the system of patronage which allowed the MPLA its huge victory were the subject of lucid comments by two analysts.

For Fernando Pacheco (2009, p 133):

The fusion between party structures and State administration remains. It was shocking to observe the way in which the public media was manipulated by the MPLA during the electoral campaign of August 2008 ... All over Angola, a significant number of civil servants did nothing in 2008 except to work for the MPLA's campaign. The Public 
Treasury should demand payment from the MPLA for at least part of the expenses incurred.

These sentiments were shared by Patrícia Ferreira (2009, pp 19-20), who posits that

[t]he MPLA is perceived, directly or indirectly, as the political force that has most contributed to stability in the country, albeit by means of a military victory, bringing peace to the population. Angola's population became increasingly urbanised during the war and Unita bases were predominantly rural. The MPLA also benefitted from a weak opposition.

The outcome of the 2008 election also reinforced one of the hallmarks of authoritarian regimes: that there is no future outside of the ruling party (Magaloni 2006, p 10).

Table 2

Results of the 2008 National Elections

\begin{tabular}{|l|c|c|c|}
\hline Party & \% Votes & Seats & \% Seats \\
\hline MPLA & 81.64 & 191 & 86.82 \\
\hline Unita & 10.39 & 16 & 7.27 \\
\hline $\begin{array}{l}\text { Social Renewal Party } \\
\text { (PRS) }\end{array}$ & 3.17 & 8 & 3.64 \\
\hline FLNA & 1.11 & 3 & 1.36 \\
\hline New Democracy (ND) & 1.20 & 2 & 0.91 \\
\hline Other parties & 2.49 & 0 & 0 \\
\hline Total & & 220 & 100 \\
\hline
\end{tabular}

Source: Amudsen 2011

The MPLA's landslide victory can, by and large, be seen as a setback for democracy in Angola. Since the election the MPLA government has shown a disrespect for civil and political rights. In addition, there has also been an increase in harassment and stricter control over the media, Parliament and the justice system.

The government has strengthened its control over civil society and the churches, a control coupled with the promise to invest in these sectors. By and large this attempt could be viewed as an effort to widen the client base of the MPLA government. 
The government also approved the new Constitution in January 2010, which provides for a single electoral system to replace the previous system, whereby there was both a presidential election and an election for the legislature. The Constitution also provides for a multiparty democracy and the division of power among the executive, the legislative branch and the judiciary.

While in theory it distinguishes between and among governmental branches and outlines their power, in reality it simultaneously reinforces the power of the president. The president of the Republic of Angola is not only the head of state, but also the head of government, the commander of the armed forces and the president of the ruling party (Amudsen \& Abreu 2006, p 3; Vines \& Weimer 2011, p 6). In addition, the president has the power to dissolve Parliament and call new elections.

The Constitution also gives the president the power to appoint a Cabinet which is accountable to him (Vines \& Weimer 2011, p 6). Parliament cannot hold the president accountable nor can he or she be voted out or censured (Amudsen \& Abreu 2006, p 3). This state of affairs suggests that 'the notion that constitutional norms and principles are binding on political leaders is still very much in doubt.' (Hyden 2006, p 18).

All these factors reinforce the notion of personal rule and accountability to the leaders as opposed to the people. Indeed, it also illustrates that formal rules enshrined in the Constitution do not have a constraining impact on the president. The entrenchment of authoritarian rule ensures that despite the mechanisms instituted to further mask the authoritarian nature of the Angolan regime, progress towards democratisation remains distant.

\section{CONCLUSION: PROBLEMS OF AND PROSPECTS FOR DEMOCRACY IN ANGOLA}

The introduction of a multiparty system in Angola following the signing of the peace agreement in 1991 did not lead to democratisation, consequently this article argues that the Angolan state can still be classified as an electoral authoritarian one. This contention is premised on the fact that the MPLA has been able to consolidate its grip on power since 1992. The fact that Unita, the major opposition party, did not accept the outcome of the parliamentary and presidential elections in 1992 and instead opted to go back to war has reinforced the authoritarian impulses of the Angolan government, which was able to consolidate its authoritarian regime under the façade of democracy through the establishment of democratic institutions.

While the 1992 elections were relatively competitive, the changes introduced by the government in the aftermath of the resumption of war meant that it was able 
to consolidate its hegemony over Angolan society. Through attempts to control and regulate civil society, legislation introduced to circumscribe participation in national elections and its level of economic control the government strengthened its authoritarian rule. The constitutional changes introduced in 2010 as a result of the resounding victory of the MPLA not only point to a lopsided distribution of power in favour of the incumbent, they also mean that the prospect of the democratisation of the Angolan body politic remains slim.

\section{- REFERENCES - -}

Adejumobi, S. 2000. 'Elections in Africa: A Fading Shadow of Democracy?' International Political Science Review 21(1).

Ake, C. 1996. Democracy and Development in Africa. Washington: Brookings Institution. Amudsen, I. 2011. 'Angolan Party Politics: Into the African Trend'. Angolan Brief 1(9). Amudsen, I \& C Abreu. 2006. Civil Society in Angola: Inroads, space and accountability. Bergen: Chr. Michelsen Institute (CMI).

Bertelsmann Stiftung. 2012. BTI 2012-Angola Country Report. Gütersloh: Bertelsmann Stiftung.

Bogaards, M. 2004. 'Counting Parties and Identifying Dominant Party Systems in Africa'. European Journal of Political Research 43(2).

Bratton, M. 1998. 'Second Elections in Africa'. Journal of Democracy 9(3).

Bratton, M \& N van de Walle. 1997. Democratic Experiments in Africa: Regime Transitions in Comparative Perspective. New York: Cambridge University Press.

Brownlee, J. 2009. 'Portents of Pluralism: How Hybrid Regimes Affect Democratic Transitions'. American Journal of Political Science 53(3).

Campos, I. 2008. Angola's Elections: A Democratic Oil Giant. London: Chatham House. Carothers, T. 1997. 'Democracy without Illusions'. Foreign Affairs 76.

Carothers, T. 2002. 'The end of the Transition Paradigm'. Journal of Democracy 13(1). De Oliveira, R. 2007. 'Business success, Angola-style: postcolonial politics and the rise and rise of Sonangol'. Journal of Modern African Studies 45(4).

Diamond, L. 2002. 'Elections without Democracy: Thinking About Hybrid Regimes'. Journal of Democracy 13(2).

Diamond, L. 2005. 'The State of Democratization at the Beginning of the $21^{\text {st }}$ Century'. The Whitehead Journal of Diplomacy and International Relations, Winter/Spring.

Ferreira, P. 2009. State-Society Relations in Angola:Peacebuilding, Democracy and Political Participation. Brussels: Initiative for Peacebuilding.

Hadenius, A \& J Teorell. 2007. 'Pathways from Authoritarianism'. Journal of Democracy 18(1). 
Heydemann, S. 2007. Upgrading Authoritarianism in the Arab World. Washington: Brookings Institution.

Hyden. G. 2006. African Politics in Comparative Perspective. Cambridge: Cambridge University Press.

Huntington. S. 1991. 'Democracy's Third Wave'. Journal of Democracy 2(2).

Joseph, R. 1997. 'Democratization in Africa after 1989: Comparative and Theoretical Perspectives'. Comparative Politics 29(3).

Levitsky, S \& L Way. 2002. 'Elections without Democracy: The Rise of Competitive Authoritarianism'. Journal of Democracy 13(2).

Levitsky, S \& L Way. 2010. Competitive Authoritarianism: Hybrid Regimes After the Cold War. New York: Cambridge University Press.

Lindberg, S. 2006. 'The Surprising Significance of African Elections'. Journal of Democracy 17(1).

Lodge, T, D Kadima \& D Pottie. 2002. Compendium of African Elections. Johannesburg: Electoral Institute of Southern Africa.

Magaloni, B. 2006. Voting for Autocracy. New York: Cambridge University Press.

Malaquias, A. 2001. 'Diamonds are a guerilla's best friend: The impact of illicit wealth on insurgency strategy'. Third World Quarterly 22(3).

Manning, C. 2005. 'Assessing African Party Systems after the Third Wave'. Party Politics 11(6).

Matlosa, K. 2008. Consolidating Democratic Governance in the SADC Region: Transitions and Prospects for Consolidation. Johannesburg: Electoral Institute of Southern Africa.

Merkel, W. 2004. 'Embedded and Defective Democracies'. Democratization 11(5).

Messiant, C. 2001. 'The Eduardo Dos Santos Foundation: Or How Angola's Regime Is Taking over Civil Society'. African Affairs 100.

Orre, A. 2010. Who's to Challenge the Party State in Angola? Political Space and Opposition in Parties and Civil Society. Bergen: Christian Michelson Institute.

Ottaway, M. 1998. 'Angola's Failed Elections'. In K Kumar (ed). Postconflict Elections, Democratization and International Assistance. Boulder, CO and London: Lynne Rienner Publishers.

Pachecho, F. 2009. 'Civil Society in Angola: Fiction or agent of change'. In P Chabal and N Vidal (eds). Southern Africa: Civil Society, Politics and Donor Strategies: Angola and its Neighbours: South Africa, Namibia, Mozambique, Democratic Republic of Congo and Zimbabwe. Lisbon: Firmamento.

Puddington, A. 2007. Freedom in the World: Freedom Stagnation amid Pushback Against Democracy. Washington: Freedom House.

Schedler, A. 2002. 'Elections without Democracy: The Menu of Manipulation'. Journal of Democracy 13(2).

Schedler, A. 2006. 'The Logic of Electoral Authoritarianism'. In A Schedler (ed). 
Electoral Authoritarianism: The Dynamics of Unfree Competition. Boulder, CO: Lynne Rienner.

Vines. A, N Shaxson, LRimli \& C Heymans. 2005. Angola: Drivers of Change. London: Chatham House

Vines, A \& M Weimer. 2011. Angola: Assessing Risks to Stability. Washington: Center for Strategic and International Studies. 